\title{
Assessment of Soil Suppressiveness to Aphanomyces Root Rot of Pea
}

\author{
L. Persson, Plant Pathology and Biological Control Unit, SLU, P.O. Box 7035, S-750 07 Uppsala, Sweden; M. \\ Larsson-Wikström, Nestlé R\&D Center Bjuv AB, P.O. Box 520, S-267 25 BJUV, Sweden; and B. Gerhardson, \\ Plant Pathology and Biological Control Unit, Uppsala
}

\begin{abstract}
Persson, L., Larsson-Wikström, M., and Gerhardson, B. 1999. Assessment of soil suppressiveness to Aphanomyces root rot of pea. Plant Dis. 83:1108-1112.

The ability of field soils to suppress pea root rot caused by Aphanomyces euteiches was assessed in field soil samples in a greenhouse bioassay and in field experiments sown with pea in monoculture for four years. In the bioassay, an inoculum of oospores in talcum powder was added to the test soils 1 week prior to sowing of pea seeds. The rate of infection was assessed 4 weeks after sowing. The field experiments were placed in six localities with varying degrees of soil suppressiveness to pea root rot and the pea yield and number of oospores of A. euteiches in root tissue were measured each year. A large variation in disease suppression was found in 24 arbitrarily chosen soils, sampled in the vining pea growing area in southern Sweden, and some soils were found to be strongly disease suppressive. The pea root rot development was also clearly different between the field experiments, depending on the soil. In an experiment on a soil showing low disease suppressiveness in the greenhouse bioassay, the crop failed in the second year, the number of oospores in root tissue increased rapidly over time, and no yield at all could be taken the fourth year. In contrast, on a soil with a high disease suppressiveness in the bioassay, the pea monoculture led to a slow build-up of oospores in root tissue and a steady high yield of $5,300 \mathrm{~kg} / \mathrm{ha}$ the fourth year.
\end{abstract}

Pea root rot caused by Aphanomyces euteiches Drechs. is the most destructive root disease of vining pea (Pisum sativum L.) in Sweden $(9,12)$ and is likewise regarded as a severe disease in other parts of Europe (10) and in pea-growing areas of North America, Australia, and Japan $(5,11)$. Highly infested fields generally remain unsafe for pea production for many years (11). So far, the most successful means of control has been to sort out highly infested fields by assessing the infestation level before sowing, thereby avoiding the disease $(9,15)$. For safe pea production, long rotations of nonhost crops between the pea crops are often needed (5). In the area of vining pea production in southern Sweden, pea is usually not grown in crop rotations more frequently than one in every six years and the soil infestation level is routinely assessed. By analyzing the outcome of assessments performed during several years, we noticed a clear geographical variation in the degree of $A$. euteiches infestation among the field soils

Corresponding author: L. Persson

E-mail: lars.persson@vpat.slu.se

The research was financed by the Swedish Council for Forestry and Agricultural Research, Nestlé R\&D Center Bjuv AB, and by the Foundation for Strategic Environmental Research (MISTRA).

Accepted for publication 25 August 1999.

Publication no. D-1999-1007-01R

(C) 1999 The American Phytopathological Society tested. In some areas, when pea was grown in a six-year crop rotation, problems with Aphanomyces root rot occurred on the third occasion; whereas, in other areas, pea could be grown every six years for at least five occasions without any problems. Crop rotations, fertilization, and climatic factors have small variations in this area; therefore, we anticipate that some unknown characteristics affecting the disease or the soil inoculum are present in the soil.

The literature contains several examples of soils in which disease incidence has been shown to remain low in spite of the presence of a pathogen and seemingly conducive conditions for disease outbreaks. Absence of severe disease has, in many of these cases, been denoted as soil disease suppression (13). Suppressiveness to different forma speciales of Fusarium oxysporum Schlechtend.:Fr. has been thoroughly investigated $(1,2,13,17)$, but the phenomenon has also been shown for a number of other soilborne pathogens (e.g., Pythium spp. and Chalara elegans Nag Raj $\&$ Kendrick $[$ synanamorph $=$ Thielaviopsis basicola (Berk. \& Broome) Ferraris]; 7,8).

Knowledge of the disease-suppressive properties of a soil may be of great practical value in predicting disease risks. For diseases such as pea root rot, where other control methods not are available, growing on disease suppressive soils might be a valuable way to reduce losses. Work in the Netherlands by Oyarzun (10) showed differences in soil receptivity to A. euteiches zoospore infection of peas in Dutch soils, indicating the feasibility of testing soils for suppressiveness to this disease.

The objective of this work was to evaluate the occurrence of soil suppressiveness to Aphanomyces root rot of pea in an area intensively grown with pea. We report on a greenhouse testing procedure suitable for large-scale soil testing using dried oospore inoculum. We also report on the relevance in the field of suppression of A. euteiches as observed in the bioassay. Field experiments assessing the effects of four years of pea monoculture were located on soils ranging from very conducive to disease suppressive according to the greenhouse bioassay. The present report deals with results from measurements of yield and number of oospores in root tissue in six field experiments run from 1994 to 1997.

\section{MATERIALS AND METHODS}

Soil sampling and storage. Field soils to be tested for disease suppression were sampled in a number of arbitrarily chosen fields grown with vining pea in the area of vining pea production in southern Sweden. All of the soils were assessed for the presence of inoculum of A. euteiches according to Olofsson (9) before the experiments with disease suppression were started, and the sampled soils and the field experiments contained no or only small amounts of inoculum. However, soil 85C contained higher amounts of inoculum. Soil samples consisting of about 10 subsamples were taken with a spade to a depth of $20 \mathrm{~cm}$ in an area of about 5 by 5 meters. All soil samples were taken during the summer when the average soil temperature at $20 \mathrm{~cm}$ depth is $15^{\circ} \mathrm{C}$ or higher (3). The samples were placed in plastic bags, taken to the laboratory, and were stored at $4^{\circ} \mathrm{C}$ for up to 6 days. A disease-conducive reference soil was used for evaluating inoculum efficiency, and was also included in all experiments to make it possible to compare results between experiments. This soil, denoted $\mathrm{R} 8$, was a loam with a $\mathrm{pH}$ of 6.3 and was taken from a field where pea has not been grown for at least 35 years.

Production of A. euteiches dried oospore inoculum. In the soil tests, we used an oospore inoculum of A. euteiches prepared from an isolate originating from a field with pea root rot in southern Sweden and denoted $5504 \mathrm{~B}$. The inoculum was produced according to a modified method originally described by Schneider (14). Plugs of A. euteiches grown on cornmeal agar were inoculated into oatmeal broth 
$(0.5 \%)$ reaching a height of $1 \mathrm{~cm}$ in rectangular glass bottles $(20$ by $30 \mathrm{~cm}$ ). After 4 weeks of incubation in the dark at about $20^{\circ} \mathrm{C}$, the mycelial mats were comminuted with a Polytron (Kinematica AG, Littau, Switzerland) at $10,000 \mathrm{rpm}$ for $2 \mathrm{~min}$. The oospore concentration in the resulting slurry was counted using a haemacytometer, and the slurry was then mixed with refined talcum powder $\left(3 \mathrm{MgO} \cdot 4 \mathrm{SiO}_{2} \cdot \mathrm{H}_{2} \mathrm{O}\right.$, 1.0:1.3, wt/wt; Riedel-de-Haën AG, Seelze, Germany). After drying this mixture for 3 weeks at room temperature, it was sieved, the concentration of oospores per gram of talcum inoculum was calculated, and the ready inoculum was then stored in darkness at $4^{\circ} \mathrm{C}$ until used.

Infectivity of each batch of inoculum was assessed by inoculating the conducive reference soil with increasing amounts of oospores $(50,100,200,500,800,1,000$, 2,000, and 3,000 oospores $/ \mathrm{ml}$ of soil). Peas were sown in the soil and disease indices were assessed as described below.

Bioassay procedure. Soil and inoculum (usually 800 to 1,000 oospores/ml of soil), giving a disease severity index of about 75 in the reference soil, were mixed in a plastic bag by vigorous shaking for $1 \mathrm{~min}$. The mixture was then filled into six plastic pots (500 $\mathrm{ml}$ each) per soil sample, and these were watered to about field capacity and left in a greenhouse at a temperature regime of $24^{\circ} \mathrm{C}$ day $/ 19^{\circ} \mathrm{C}$ night. Extra light (Osram, HQI-T $400 \mathrm{~W}$ ) was supplied for $16 \mathrm{~h}$ /day. After 7 days, 10 pea seeds of cv. Tristar treated with metalaxyl (Apron 200 LS, $20 \%$ a.i.) were sown in each pot. The pots were then again placed in the greenhouse and were watered daily to about field capacity to give optimal conditions for infection. After 4 weeks, the pea plants were removed from the pots and the roots were washed in water, then divided into seven disease severity classes, ranging from 0 (healthy plants) to 100 (dead plants) according to Persson et al. (12). An average disease severity index (DSI) was then calculated for each tested soil.

Locations, soil characteristics, and the performance of the field experiments. Experiments of pea cultivated in monoculture on six field soils, denoted as numbers 80 to 85 , were started in 1994 . The experiments were located in fields ranging from low to high in soil suppressiveness to pea root rot according to the bioassay. All experiments were placed on field soils that could be texturally characterized as loam soils. The soil $\mathrm{pH}$ ranged between 6.2 and 7.7 and the soil organic matter content between 1.7 and $2.8 \%$. All soils had been cultivated with pea approximately every sixth year for at least five crop rotations. Other crops in the rotation were sugar beet and cereals, mainly winter wheat and barley. The experiments were situated within a longest distance of $35 \mathrm{~km}$ from each other and with similar climatic conditions. Each experiment consisted of four plots, each 3 by 10 meters in size, placed beside each other. Pea cv. Tristar, commonly grown in the area, was sown each spring in April using $200 \mathrm{~kg} / \mathrm{ha}$. The seed was treated with metalaxyl (Apron $200 \mathrm{LS}, 20 \%$ a.i.), the experiments were fertilized, and weeds and insects were controlled chemically according to recommendations in this area for a commercially grown pea crop. The peas in each plot were harvested at the same maturity stage as in a commercially grown vining pea crop, and the yield was measured. In a few cases, the yield data were not used in the evaluations due to damage by birds.

Disease assessment in field experiments. Each year, at the beginning of the flowering stage, 10 plants were taken to a depth of approximately $20 \mathrm{~cm}$ at four randomly chosen places in each plot, yielding 40 plants per plot and 160 plants per experiment. To give a measure of the infection of A. euteiches, the numbers of oospores in the roots were counted. Three plants were randomly sampled from each sample of 10 plants, giving 12 plants from each plot. The roots of these plants were cut off at the seed level and the total weight of the 12 roots was measured. The roots were then chopped into pieces and comminuted with a Polytron (Kinematica AG, Littau, Switzerland), at 10,000 rpm for $2 \mathrm{~min}$ in $100 \mathrm{ml}$ of tap water. The oospore concentration in the resulting slurry was counted using a hemacytometer and the number of oospores per gram of root fresh weight was calculated. In a few cases, oospore counting data from the outer plots were excluded from the statistical analysis where it was apparent from the data that an intermixture of uninfested soil from outside the experiment had occurred due to soil tillage.
The presence of root pathogens was also assessed by isolations from roots of the plants sampled from each plot. A section of each root was placed on selective agar media and the outgrown fungi were pure cultured and identified as described by Persson et al. (12).

\section{RESULTS}

Inoculum infectivity. All batches of oospore inocula produced showed about the same infectivity at a given oospore concentration. An inoculum dose of $\geq 500$ oospores/ml of soil resulted in an adequate infection (i.e., a DSI of around 75 in the conducive reference soil). A typical dose response curve is shown in Figure 1. The oospore inoculum could be stored at $4^{\circ} \mathrm{C}$ for at least 13 months without loss of infectivity.

Variation in disease suppression among sampled field soils. In bioassaying 24 field soils sampled in the summer, we obtained a wide variation in severity of pea root rot after inoculation with A. euteiches (Fig. 2). The most conducive soil showed a DSI of 99 and one soil, showing a high degree of disease suppressiveness, reached a DSI of only 3.

Yield measurements in field experiments. In the fourth year of pea monoculture, the soil in field experiment 85 , which was highly disease suppressive in the bioassay, gave a yield $(5,300 \mathrm{~kg} / \mathrm{ha})$ that was above the average for the area $(5,000$ $\mathrm{kg} / \mathrm{ha}$ ) and significantly higher than the yield from other experiments $(P<0.0001$; Table 1). For the other soils in experiments 80 to 84 , the yields had been decreasing over the years, but to a varying degree. On a conducive soil, such as field experiment 80 , the yield decreased rapidly each year of monoculture and almost no crop was taken the last year (Table 1).

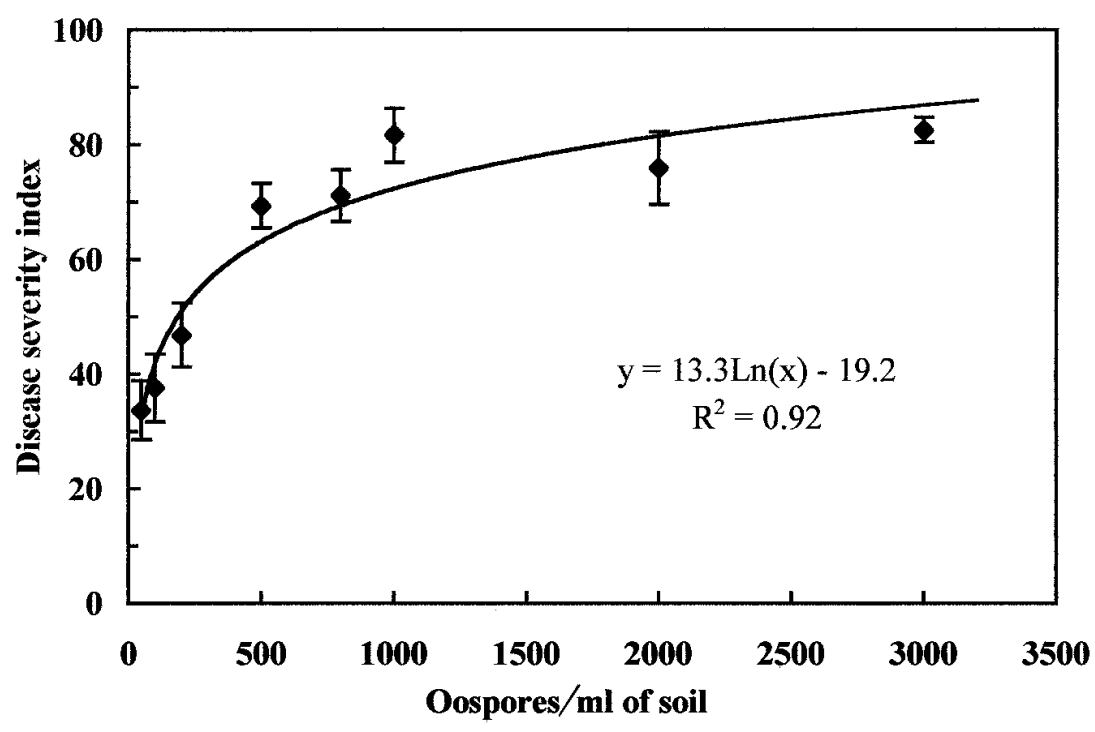

Fig. 1. Mean disease severity index (DSI) of 4-week-old pea plants grown in the conducive reference soil (R8) mixed with increasing amounts of inoculum (oospores) of Aphanomyces euteiches. Means and standard errors are calculated from two independent experiments. 
Disease assessment in field experiments. After the first year of pea growing, no oospores of $A$. euteiches were found in the roots of sampled plants in experiments 81 and 85 , but small numbers of oospores were present in experiments 80,82 , and 84 (Table 1). In experiment 83, large numbers of oospores could be found the first year and a very high number of oospores the second year, implying that A. euteiches was established in this soil. In the experiment placed on a highly suppressive soil (85), oospores could not be found until the third year of pea monoculture. In the fourth year, the number of oospores was still very low $(2,900$ oospores/g of root; Table 1), which was significantly lower $(P<0.05)$ than in experiments 80 to 83 . A strong relationship $\left(R^{2}=0.74\right)$ was found between the DSI assessed in the bioassay and the highest number of oospores found per gram of root, which occurred the fourth year of pea monoculture, except in field experiment 83 (Fig. 3). There was also a good relationship $\left(R^{2}=0.66\right)$ between the number of oospores per gram of root and yield (Fig. 4).

The fungal species isolated from the pea roots sampled in the field experiments were similar to those found in a previous survey performed in this pea growing area (12). The isolation frequencies of $\mathrm{A}$. $\mathrm{eu}$ teiches and Pythium spp. increased in all field experiments during the period, but no increase could be seen for Fusarium spp. and Phoma medicaginis Malbr. \& Roum. var. pinodella (L. K. Jones) (data not shown).

\section{DISCUSSION}

By applying a greenhouse bioassay procedure as outlined in this article, we were able to measure clear differences between field soil samples in their capacity to promote or suppress pea root rot induced by infection of A. euteiches (Fig. 2). A specific field soil gave consistent DSI in the bioassay when sampled repeatedly in the same season; therefore, we regard this disease-suppression capacity as a measurable soil characteristic. Large differences in the Aphanomyces root rot development were found in the field experiments of pea monoculture in six locations. On a soil that exhibited a high DSI in the greenhouse bioassay (i.e., a low degree of suppressiveness), a severe infestation developed, and the crop failed in the second year. However, in a soil with a low DSI in the bioassay (i.e., a high degree of suppressiveness),

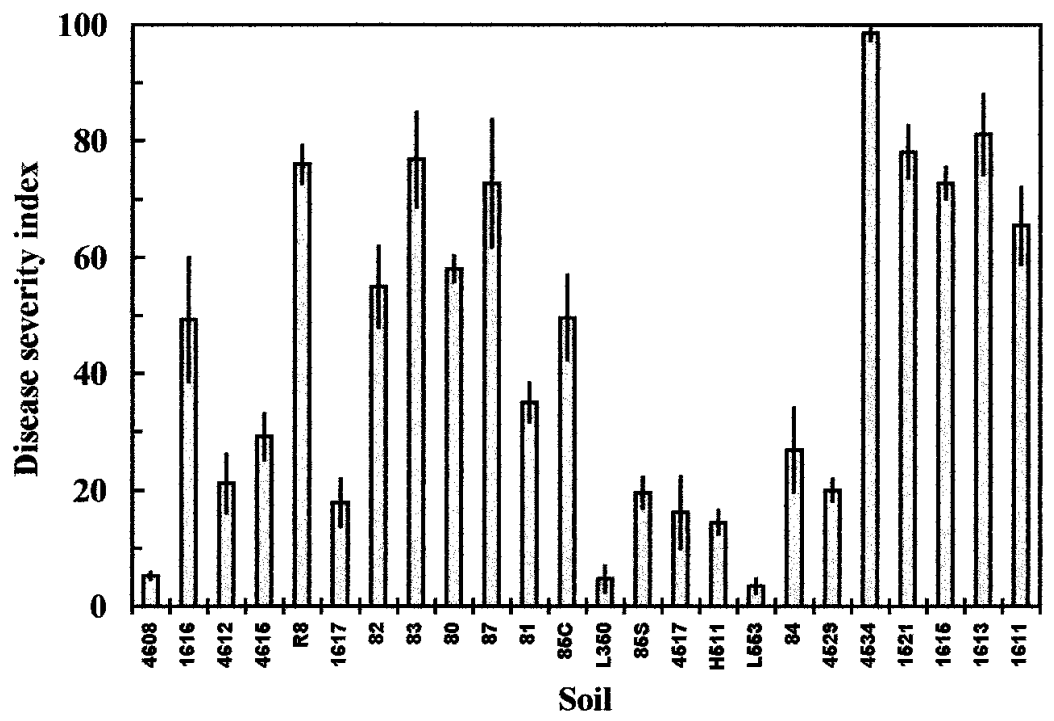

Fig. 2. Mean disease severity index (DSI) in a greenhouse test of 24 soils from southern Sweden after inoculation with Aphanomyces euteiches (usually 800 to 1,000 oospores/ml of soil). Least significant difference $=15.5(P=0.05)$. Bars indicate standard error of the mean. an equal pea monoculture led to a markedly slower build-up of disease and, even after four years of monoculture, the yield was still above the average yield for the area (Table 1). The number of oospores of A. euteiches per gram of root likewise developed differently depending on the soil. It rapidly increased in the soil with a high DSI but remained low in the soil with a low DSI in the greenhouse bioassay (Table 1), which indicates differences in build-up of soil inoculum. The pathogen, A. euteiches, was present at least from the third year in all experiments, and the climatic conditions were similar between the locations; therefore, we regard these differences in development of yields and oospore contents of roots as being dependent on differences in soil characteristics. It appears that the phenomenon could be classified as differences in soil disease suppressiveness (e.g., as defined by Alabouvette; 1). We also conclude that our assessments of the degree of soil suppressiveness to pea root rot carried out in a greenhouse bioassay have clear relevance to field conditions and reflect the inclination of the soil for development of Aphanomyces root rot.

In most field soils, the number of oospores in the root tissue increased due to continuous pea growing and usually were highest in the last experimental year (Table 1). This is in agreement with the wellknown fact that a severe infestation of Aphanomyces root rot results in large numbers of oospores, serving as inoculum for the following seasons (5). Our method of counting the number of oospores per gram of root gave results that corresponded well to the yield obtained (Fig. 4), suggesting that $A$. euteiches was the major cause of the yield decline in these experiments. Furthermore, despite high isolation frequencies of other pathogens in the field experiments, the yield remained stable during the four years in the suppressive soil, again suggesting that $A$. euteiches was the major cause of the yield reductions in the experiments placed on the conducive soils.

Bioassay procedures similar to the one adopted here have successfully been used for measuring soil suppressiveness to several other soil-borne diseases $(1,6,10)$. Suppressiveness measured in these bioassays has often been preceded by observa-

Table 1. Yield and number of oospores of Aphanomyces euteiches in root tissue in pea monoculture field experiments in 1994 to $1997^{\mathrm{y}}$

\begin{tabular}{|c|c|c|c|c|c|c|c|c|}
\hline \multirow[b]{2}{*}{ Experiment no. } & \multicolumn{4}{|c|}{ Yield (kg/ha) } & \multicolumn{4}{|c|}{ Oospores $($ No. $\times 1,000 / g$ of root) } \\
\hline & 1994 & 1995 & 1996 & 1997 & 1994 & 1995 & 1996 & 1997 \\
\hline 80 & $4,600 \mathrm{c}$ & $2,100 \mathrm{~b}$ & $2,700 \mathrm{c}$ & $400 \mathrm{~d}$ & $0.89 \mathrm{~b}$ & $13.3 \mathrm{~b}$ & $10.9 \mathrm{c}$ & $137.9 \mathrm{~b}$ \\
\hline 81 & $2,800 \mathrm{~d}$ & $3,500 \mathrm{a}$ & $7,200 \mathrm{a}$ & $200 \mathrm{de}$ & $0 \mathrm{~b}$ & $0.83 \mathrm{~b}$ & $6.3 c$ & $75.5 \mathrm{c}$ \\
\hline 82 & $2,900 \mathrm{~d}$ & $4,000 \mathrm{a}$ & $1,600 \mathrm{~d}$ & $0 \mathrm{e}$ & $0.17 \mathrm{~b}$ & $16.5 \mathrm{~b}$ & $99.4 \mathrm{a}$ & $196.5 \mathrm{a}$ \\
\hline 83 & $5,600 \mathrm{ab}$ & $1,400 \mathrm{c}$ & $1,600 \mathrm{~d}$ & $2,600 \mathrm{c}$ & $18.1 \mathrm{a}$ & $148.1 \mathrm{a}$ & $63.0 \mathrm{~b}$ & $74.8 \mathrm{c}$ \\
\hline 84 & $5,400 \mathrm{~b}$ & $\ldots^{\mathrm{z}}$ & $6,000 \mathrm{~b}$ & $3,700 \mathrm{~b}$ & $3.6 \mathrm{~b}$ & $14.8 \mathrm{~b}$ & $1.9 \mathrm{c}$ & $18.2 \mathrm{~d}$ \\
\hline 85 & $5,900 \mathrm{a}$ & $\ldots^{\mathrm{z}}$ & $5,600 \mathrm{~b}$ & $5,300 \mathrm{a}$ & $0 \mathrm{~b}$ & $0 \mathrm{~b}$ & $1.5 \mathrm{c}$ & $2.9 \mathrm{~d}$ \\
\hline
\end{tabular}

y Means in each column followed by the same letter are not significantly different $(P \leq 0.05)$ according to Duncan's multiple range test.

${ }^{\mathrm{z}}$ Yield not taken. 

plant production. Soil receptivity to Aphanomyces root rot has earlier been investigated in the Netherlands by Oyarzun (10), who worked out a specific bioassay. He inoculated soil samples with zoospores of A. euteiches and measured the disease severity induced under strictly controlled conditions using computerized equipment. the Netherlands were conducive, but a few soils clearly reduced infection of $A$. euteiches. However, these results were not confirmed by observations in the field. Zoospores are sensitive to environmental conditions and survive for only a few days (11). If adverse conditions are prevailing even for a short time, the zoospores may tions of absence of disease in commercial He found that most of the tested soils from

lose their ability to infect the plant. The use of zoospores as inoculum, therefore, probably requires a very carefully controlled environment. Oospore inoculum, on the other hand, may remain viable for 10 to 15 years in the soil (4) and is also known to be influenced by bacteria and fungi in the soil (16). Our artificially produced oospore inoculum could be stored for at least one year at $4{ }^{\circ} \mathrm{C}$ without loss of infectivity, which also has been shown by others (14). This ability for long-time storage greatly facilitates long series of soil testing. We were searching for a method suitable for routine prediction of disease risks in commercial pea cropping; therefore, we preferred an oospore inoculum that could be dried and

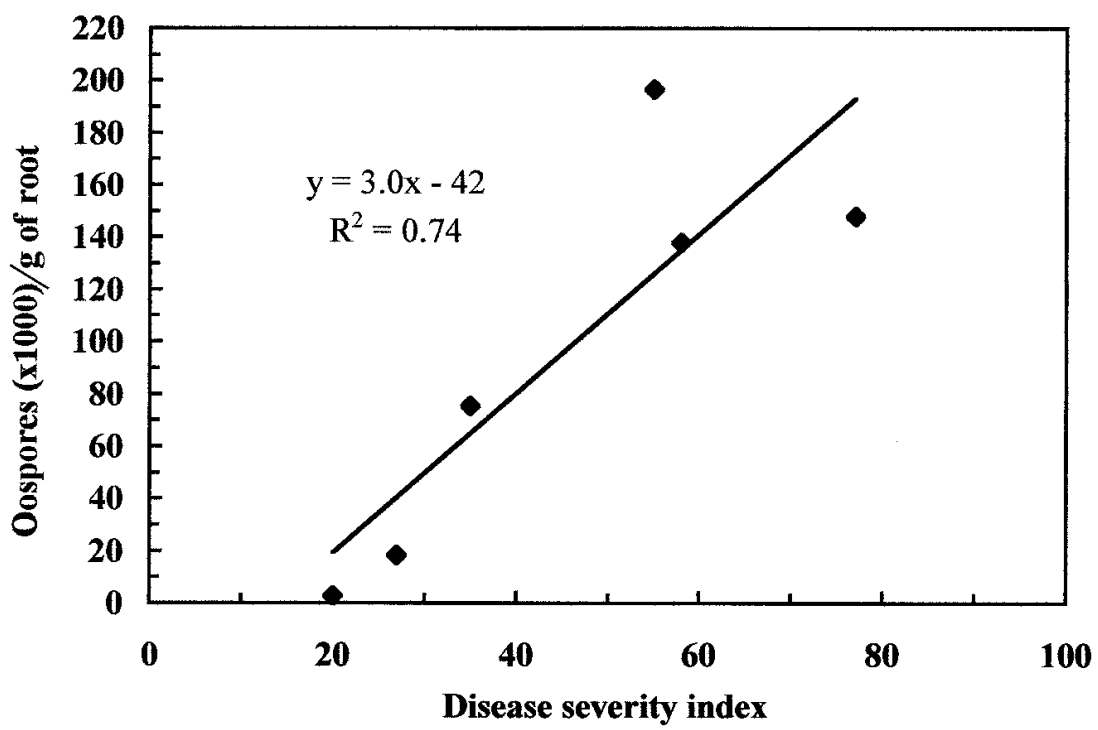

Fig. 3. Relationship between mean disease severity index of six inoculated soils in a greenhouse bioassay and the mean number of oospores of Aphanomyces euteiches in root tissue after four years of pea monoculture in field experiments on these soils.

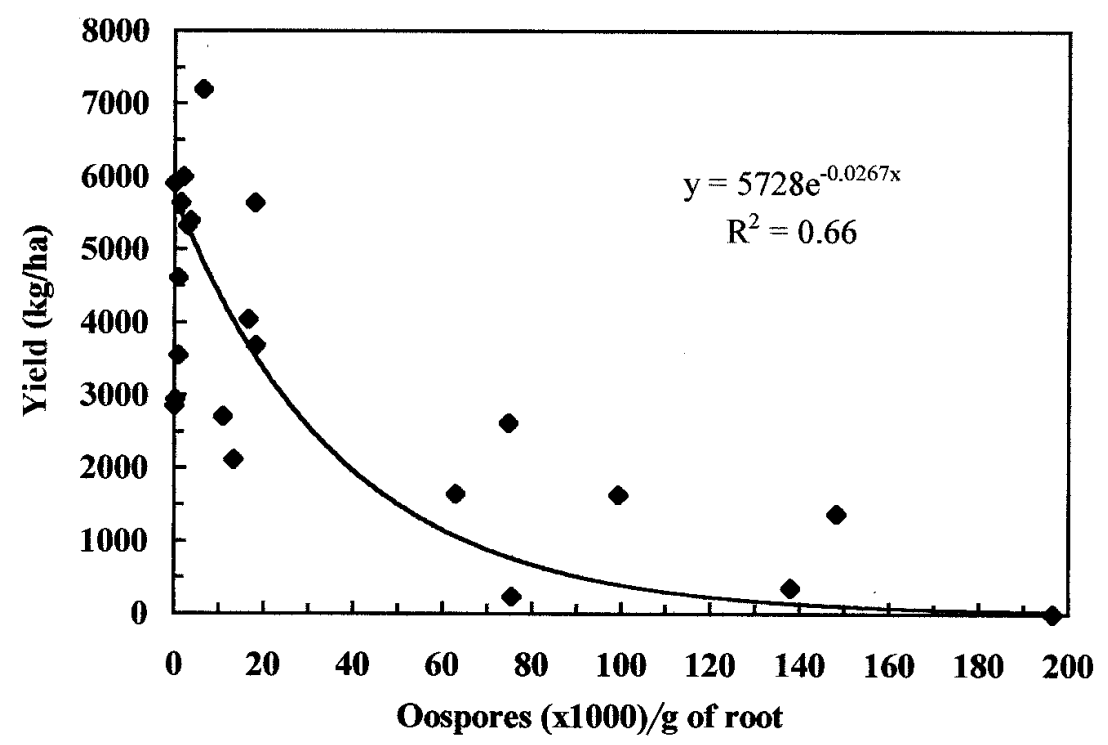

Fig. 4. Relationship between the number of oospores of Aphanomyces euteiches in root tissue and yield in six field experiments grown with pea monocultures from 1994 to 1997. Each data point represents the yearly mean of one field experiment with four blocks. stored and a less expensive and laborintensive greenhouse test.

Interestingly, the season of soil sampling was found to influence the outcome of the bioassay described. Indications from various experiments (L. Persson, unpublished) led us to assume that soil disease suppression assessed in the bioassay is less pronounced if the soil is sampled during the winter, when the average soil temperature is below $1^{\circ} \mathrm{C}$ (3). Due to these findings, we conclude that, for routine soil testing in the area concerned, soil sampling should be done during the summer and care should be taken when comparing and interpreting results from bioassays performed during different seasons.

Disease suppression has been described for various diseases, but there are few reports on soils suppressive to Oomycetes, especially A. euteiches. The crop rotations used are similar in the investigated growing area; therefore, the mechanisms appear to be associated with other differences related to the soils. There is a variation in geological origin of the soils in this area, caused by the historical movements of continental glaciers and deposition of material during the glacial period (18). These facts imply that disease suppression might be due to differences in soil abiotic factors. However, preliminary experiments with heat treatment and $\lambda$-irradiation ( $L$. Persson, unpublished), as well as the indications that disease suppression was more pronounced when soils were sampled in the warm season, point to a biological origin of the suppressiveness. There is probably a combination of several factors causing disease suppression, as has been shown for other pathogens $(1,13)$.

From a practical point of view, our field experiments confirm the possibility of monitoring field soils routinely for suppressiveness to pea root rot with a simple greenhouse bioassay. Knowledge of this characteristic can be used for an effective control strategy of pea root rot through risk assessments and planning of the crop rotation.

\section{ACKNOWLEDGMENTS}

We thank personnel at Nestlé R\&D Center Bjuv $\mathrm{AB}$ for technical assistance.

\section{LITERATURE CITED}

1. Alabouvette, C. 1986. Fusarium-wilt suppressive soils from the Châteaurenard region: review of a 10-year study. Agronomie 6:273284.

2. Amir, H., and Alabouvette, C. 1993. Involvement of soil abiotic factors in the mechanisms of soil suppressiveness to Fusarium wilts. Soil. Biol. Biochem. 25:157-164.

3. Ångström, A. 1974. Sveriges Klimat. Generalstabens Litografiska Anstalts Förlag, Stockholm.

4. Boosalis, M. G., and Scharen, A. L. 1959. Methods for microscopic detection of Aphanomyces euteiches and Rhizoctonia solani and for isolation of Rhizoctonia solani associated with plant debris. Phytopathology 49:192198.

Plant Disease / December 19991111 
5. Hagedorn, D. J., ed. 1984. Compendium of Pea Diseases. American Phytopathological Society, St. Paul, MN.

6. Lumsden, R. D., Garcia-E., R., Lewis, J. A., and Frías-T., G. A. 1987. Suppression of damping-off caused by Pythium spp. in soil from the indigenous Mexican chinampa agricultural system. Soil. Biol. Biochem. 19:501508.

7. Martin, F. N., and Hancock, J. G. 1986. Association of chemical and biological factors in soils suppressive to Pythium ultimum. Phytopathology 76:1221-1231.

8. Meyer, J. R., Shew, H. D., and Harrison, U. J. 1994. Inhibition of germination and growth of Thielaviopsis basicola by aluminum. Phytopathology 84:598-602.

9. Olofsson, J. 1967. Root rot of canning and freezing peas in Sweden. Acta Agric. Scand.
17:101-107.

10. Oyarzun, P. J. 1994. Root rot of peas in The Netherlands; fungal pathogens, inoculum potential and soil receptivity. Thesis. Wageningen.

11. Papavizas, G. C., and Ayers, W. A. 1974 Aphanomyces species and their root diseases in pea and sugar beet. U. S. Dep. Agric. Agric. Res. Serv. Tech. Bull. No. 1485.

12. Persson, L., Bødker, L., and Larsson-Wikström, M. 1997. Prevalence and pathogenicity of foot and root rot pathogens of pea in southern Scandinavia. Plant Dis. 81:171-174.

13. Scher, F. M., and Baker, R. 1980. Mechanism of biological control in a Fusarium-suppressive soil. Phytopathology 70:412-417.

14. Schneider, C. L. 1978. Use of oospore inoculum of Aphanomyces cochlioides to initiate blackroot disease in sugar beet seedlings. J.
Am. Soc. Sugar Beet Technol. 20:55-62.

15. Sherwood, R. T., and Hagedorn, D. J. 1958 Determining common root rot potential of pea fields. Wis. Exp. Stn. Bull. 531.

16. Sneh, B., Humble, S. J., and Lockwood, J. L. 1977. Parasitism of oospores of Phytophthora megasperma var. sojae, $P$. cactorum, Pythium sp., and Aphanomyces euteiches in soil by oomycetes, chytridiomycetes, hyphomycetes, actinomycetes, and bacteria. Phytopathology 67:622-628.

17. Stotzky, G., and Martin, R. T. 1963. Soil mineralogy in relation to the spread of Fusarium wilt of banana in Central America. Plant Soil 18:317-337.

18. Wiklander, L., and Lotse, E. 1966. Mineralogical and physico-chemical studies on clay fractions of Swedish cultivated soils. Lantbrukhögsk. Ann. 32:439-475 